\title{
ДОСЛІДЖЕННЯ ЛЕТКИХ КОМПОНЕНТІВ БЕДРИНЦЮ ЛОМИКАМЕНЕВОГО (PIMPINELLA SAXIFRAGA L.)
}

Вступ. В Україні зростає 5 видів рослин роду Бедринець родини селерові (Аріасеае). Найпоширенішим $\epsilon$ бедринець ломикаменевий (Pimpinella saxifraga L.) - багаторічна трав'яниста рослина, типовий представник роду Pimpinella. На сьогодні достатньо інформації щодо його застосування в народній медицині: відвари підземних органів рослини як відхаркувальний засіб при тривалому кашлі, фрарингіті, ларингіті, трахеїті та хронічному бронхіті; при лікуванні захворювань шлунково-кишкового тракту (метеоризм, порушення травлення, хронічний гастрит, ентероколіт). Використовують рослину також як протизапальний та гіпотензивний засіб.

У доступних джерелах наукової літератури недостатньо інфрормації про хімічний склад бедринцю ломикаменевого. Відсутні відомості про дослідження його летких сполук. 3 огляду на це і те, що ефрірні олії представників родини Аріасеае широко застосовують у народній та науковій медицині як антибактеріальні, протигрибкові, противірусні, протипаразитарні, інсектицидні, спазмолітичні, відхаркувальні, протизапальні засоби, метою дослідження було вивчити леткі сполуки бедринцю ломикаменевого трави та кореневищ і коренів, встановити їх компонентний склад.

Методи дослідження. Компонентний склад летких сполук досліджували хроматограсрічним методом на хромато-мас-спектрометричній системі Agilent 6890N/5973 inert (Agilent Technologies, США). Iдентифрікацію компонентів проби здійснювали з використанням бібліотеки мас-спектрів NIST 02.

Результати й обговорення. У результаті проведених досліджень у бедринцю ломикаменевого траві виявлено 59 компонентів летких сполук, з них ідентифріковано 26, основними з яких є гермакрен-D, $\beta$-бісаболен, гептакозан та нонакозан. У траві досліджуваного об'єкта виявлено сесквітерпеновий спирт $\alpha$-бергамотол, який може бути маркерною сполукою леткої фрракції трави рослини. У Pimpinella saxifraga $L$. коренях виявлено 65 компонентів летких сполук, з них ідентифріковано 27, основними з яких є каріофрілен, n-гексадеканова і 9,12-октадекадієнова кислоти, гермакрен-D та $\beta$-гур'юнен. Спільними компонентами бедринцю ломикаменевого трави і підземних органів $\epsilon \beta$-орарнезен, гермакрен- $D$, $\beta$-бісаболен, 1 , 3-диметилнасртален та n-гексадеканова кислота.

Висновки. Методом газової хромато-мас-спектрометрії досліджено якісний склад летких сполук бедринцю ломикаменевого трави та корененевищ і коренів. У траві виявлено 59 компонентів, ідентифіковано 26. У кореневищах і коренях ідентифріковано 27 компонентів із 65 виявлених. Основними компонентами бедринцю ломикаменевого трави є гермакрен-D, $\beta$-бісаболен, гептакозан, нонакозан; кореневищ $i$ коренів - каріофрілен, n-гексадеканова і 9,12-октадекадієнова кислоти, гермакрен-D та $\beta$-гур'юнен. Спільними компонентами підземних і надземних органів рослини $\epsilon \beta$-срарнезен, гермакрен-D, $\beta$-бісаболен, 1,3-диметилнафтален та п-гексадеканова кислота. Встановлено маркерну сполуку леткої фрракції бедринцю ломикаменевого трави - $\alpha$-бергамотол.

КЛЮЧОВІ СЛОВА: бедринець ломикаменевий; трава; кореневища і корені; газова хромато-мас-спектрометрія; леткі сполуки.

ВСТУП. Бедринець ломикаменевий (Рimpinella saxifraga L.) - багаторічна трав'яниста рослина, типовий представник роду Бедринець (Pimpinella) родини селерові (Аріасеае). 3 відомих 200 видів рослин роду Бедринець в Україні зростає 5. Бедринець ломикаменевий є найпоширенішим видом [1].

На сьогодні достатньо інфрормації щодо застосування бедринцю ломикаменевого в народній медицині при різних патологіях. $€$ дані, що відвари цієї рослини вживають як відхаркуваль(с Е. А. Паращук, С. М. Марчишин, Л. В. Слободянюк, 2018. ний засіб при тривалому кашлі, фрарингіті, ларингіті, трахеїті та хронічному бронхіті, що бедринцю ломикаменевого надземна частина, завдяки наявності клітковини, допомагає нормалізувати обмінні процеси, є хорошим засобом при запорах. У болгарській народній медицині його використовують при лікуванні захворювань шлунково-кишкового тракту (метеоризм, порушення травлення, хронічний гастрит та ентероколіт). Бедринцю ломикаменевого кореневища і корені також застосовують як протизапальний та гіпотензивний засіб [2, 3]. 
Попереднє вивчення хімічного складу бедринцю ломикаменевого трави та кореневищ i коренів показало, що сировина містить фрлавоноїди, кислоти гідроксикоричні, дубильні речовини, кумарини й амінокислоти [4, 5].

У доступних джерелах наукової літератури недостатньо інформації про хімічний склад бедринцю ломикаменевого. Відсутні відомості про дослідження його летких сполук. 3 огляду на це і те, що ефрірні олії представників родини Apiaceae широко застосовують у народній та науковій медицині як антибактеріальні, протигрибкові, противірусні, протипаразитарні, інсектицидні, спазмолітичні, відхаркувальні, протизапальні засоби [6], метою дослідження було вивчити леткі сполуки бедринцю ломикаменевого трави та кореневищ і коренів, встановити їх компонентний склад.

МЕТОДИ ДОСЛІДЖЕННЯ. Об'єкТами Досліджень були бедринцю ломикаменевого трава та кореневища і корені, які заготовляли на трав'янистих пагорбах і схилах у Гусятинському районі Тернопільської області у 2014 р. (траву в липні - серпні, кореневища і корені - восени після відмирання надземної частини рослини).

Компонентний склад летких сполук досліджували хроматографрічним методом [7] на хромато-мас-спектрометричній системі Agilent $6890 N / 5973$ inert (Agilent Technologies, США). Колонка капілярна HP-5MS, довжина - 30 м, внутрішній діаметр - 0,25 мм, товщина фрази 0,25 мкм.

Леткі сполуки бедринцю ломикаменевого трави та коренів одержували методом перегон- ки 3 водяною парою з використанням зворотного холодильника за температури $100{ }^{\circ} \mathrm{C}$ упродовж 3 год. Відігнані води екстрагували гептаном. Екстракт упарювали до 100-200 мкл у потоці азоту $[8,9]$. Компоненти летких сполук рослини аналізували в градієнтному режимі. Початкову температуру $50^{\circ} \mathrm{C}$ витримували впродовж 5 хв із наступним градієнтом $4^{\circ} \mathrm{C} / \mathrm{xв}$ до $220^{\circ} \mathrm{C}$, із градієнтом $10^{\circ} \mathrm{C} /$ хв до $300^{\circ} \mathrm{C}$ - протягом 10 хв, газ-носій - гелій, швидкість потоку через колонку - 1,0 мл/хв. Температура випаровувача $-300^{\circ} \mathrm{C}$, режим вводу проби з поділом потоку (split) із коесріцієнтом 1:50, об'єм інжекції 2 мкл. Ідентисрікацію компонентів проби здійснювали 3 використанням бібліотеки мас-спектрів NIST 02.

РЕЗУЛЬТАТИ Й ОБГОВОРЕННЯ. ХРОМаТОграми летких сполук бедринцю ломикаменевого трави та кореневищ і коренів представлено на рисунках 1, 2. Результати визначення компонентного складу летких сполук досліджуваних об'єктів наведено в таблицях 1 i 2.

У результаті проведених досліджень у бедринцю ломикаменевого траві виявлено 59 компонентів летких сполук, з них ідентифріковано 26 (табл. 1). Основними компонентами $€$ гермакрен-D, $\beta$-бісаболен, гептакозан, нонакозан (збіг 99 \%). У траві досліджуваного об'єкта виявлено сесквітерпеновий спирт - $\alpha$-бергамотол (збіг $90 \%)$, який може бути маркерною сполукою леткої фрракції бедринцю ломикаменевого трави.

У Pimpinella saxifraga L. коренях виявлено 65 компонентів летких сполук, з них ідентифріковано 27 (табл. 2). Основними сполуками є каріо-

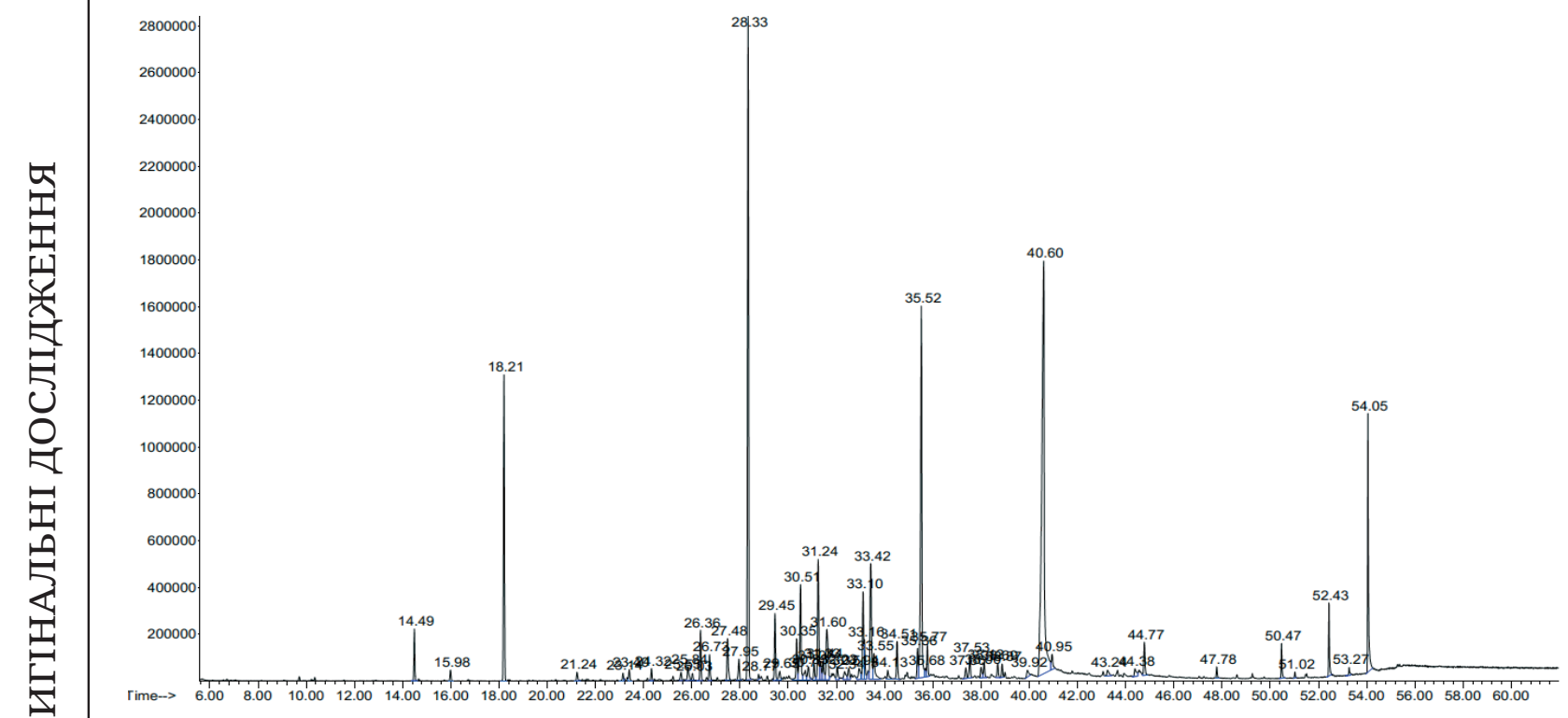

Рис. 1. Хроматограма летких сполук Pimpinella saxifraga L. трави. 
фрілен, n-гексадеканова і 9,12-октадекадієнова кислоти (збіг - 99 \%); гермакрен-D та $\beta$-гур'юнен (збіг - $98 \%$ ).

Порівнюючи компонентний склад летких сполук у бедринцю ломикаменевого траві та кореневищах і коренях, слід відмітити, що спільними компонентами підземних і надземних органів рослини $є \beta$-орарнезен, гермакрен-D, $\beta$-бісаболен, 1,3-диметилнасртален та $n$-гексадеканова кислота.

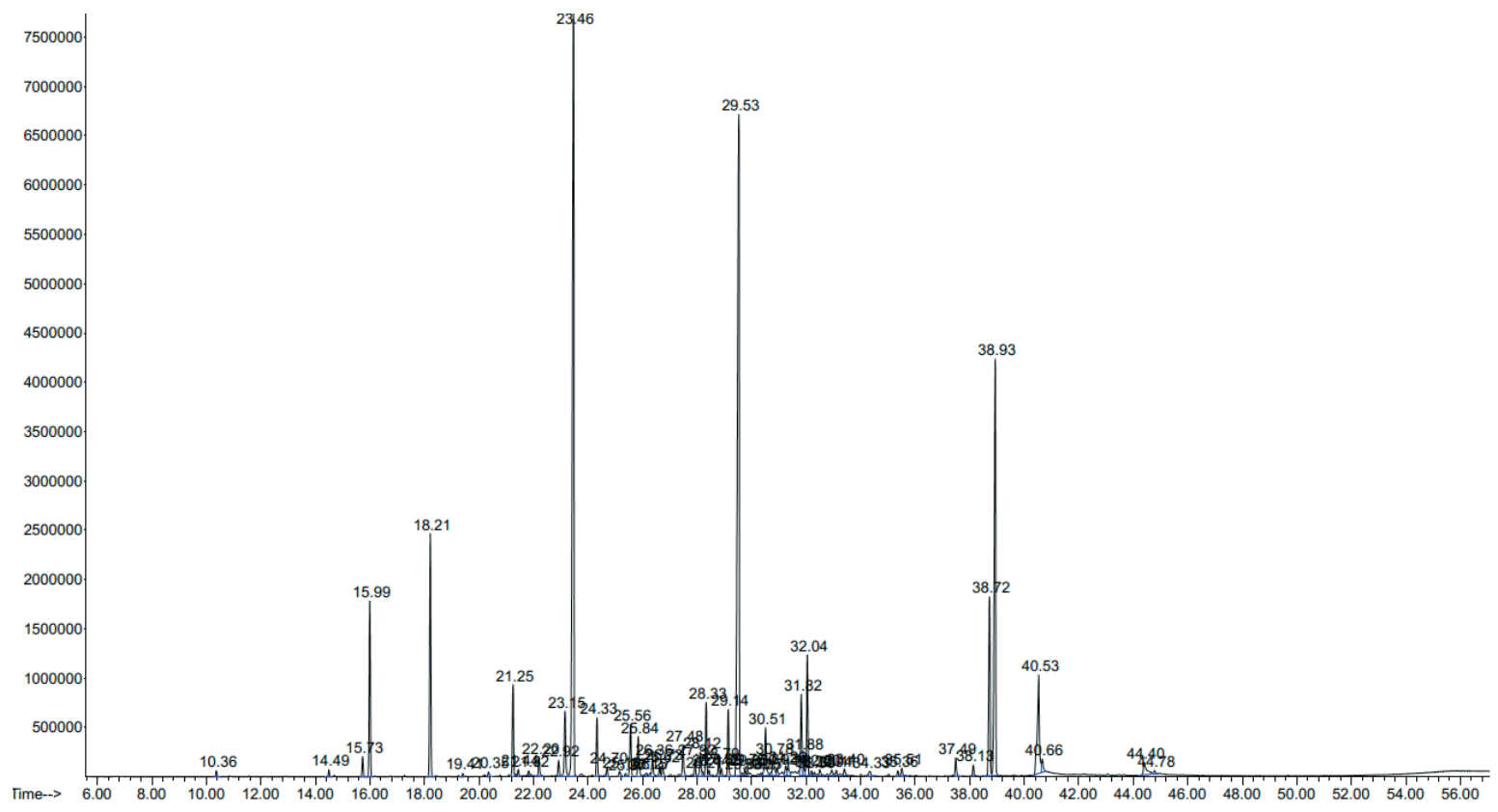

Pис. 2. Хроматограма летких сполук Pimpinella saxifraga L. коренів.

Таблиця 1 - Вміст летких сполук у бедринцю ломикаменевого траві

\begin{tabular}{|c|c|c|c|}
\hline № 3/ח & Час утримання & Назва компонента леткої сполуки & MC, \% \\
\hline 1 & 14,48 & ундекан & 94 \\
\hline 2 & 18,20 & 4-(2-бутеніл)-1,2-диметил бензен & 90 \\
\hline 3 & 23,40 & 1-метилпента-1,3-диеніл бензен & 87 \\
\hline 4 & 25,55 & $\beta$-каріофрілен & 89 \\
\hline 5 & 26,02 & 1,6-диметилнасртален & 97 \\
\hline 6 & 26,36 & 1,1,3-триметил-1Н-інден & 90 \\
\hline 7 & 26,73 & $\beta$-орарнезен & 94 \\
\hline 8 & 27,48 & гермакрен-D & 99 \\
\hline 9 & 27,95 & біциклогермакрен & 93 \\
\hline 10 & 28,33 & $\beta$-бісаболен & 99 \\
\hline 11 & 29,45 & 1,3-диметилнастален & 95 \\
\hline 12 & 30,35 & декагідро-1,1,7-триметил-4-метилен-1Н-циклопроп[е]азулен-7-ол & 99 \\
\hline 13 & 30,51 & каріофілен оксид & 93 \\
\hline 14 & 31,24 & $\alpha$-бергамотол & 90 \\
\hline 15 & 32,94 & 2-алілфенол & 80 \\
\hline 16 & 33,10 & 2-(2-піридил) циклогексанол & 90 \\
\hline 17 & 37,53 & 6,10,14-триметил-2-пентадеканон & 91 \\
\hline 18 & 37,99 & пентадеканова кислота & 93 \\
\hline 19 & 38,87 & [4-метокси-2-(3-метилоксиран-2-іл) феніл] 2-метилбутаноат & 89 \\
\hline 20 & 40,59 & n-гексадеканова кислота & 99 \\
\hline 21 & 44,38 & ейкозен-3 & 86 \\
\hline 22 & 47,78 & пентадекан & 95 \\
\hline 23 & 50,47 & хенейкозан & 91 \\
\hline 24 & 51,02 & біс (2-етилгексил) фрталат & 80 \\
\hline 25 & 52,43 & гептакозан & 99 \\
\hline 26 & 54,05 & нонакозан & 99 \\
\hline
\end{tabular}

Примітка. Тут і в таблиці 2: MC, \% - відсоток збігу зі сполуками бібліотеки мас-спектрів NIST 02. 
Таблиця 2 - Вміст летких сполук у бедринцю ломикаменевого кореневищах і коренях

\begin{tabular}{|c|c|c|c|}
\hline № 3/ח & Час утримання & Назва компонента леткої сполуки & $\overline{\mathrm{MC}, \%}$ \\
\hline 1 & 10,37 & 2-пентил-фруран & 91 \\
\hline 2 & 14,49 & ундекан & 97 \\
\hline 3 & 15,99 & 1-метил-5,6-дивініл-1-циклогексен & 87 \\
\hline 4 & 18,22 & 2,3 диметил-4-френіл-2-бутен & 89 \\
\hline 5 & 19,41 & метилтимол & 90 \\
\hline 6 & 21,44 & транс 2,4-декадієналь & 90 \\
\hline 7 & 21,82 & 4-(2-бутеніл)-1,2-диметил бензен & 93 \\
\hline 8 & 23,15 & 1-метилпента-2,4-диеніл бензен & 90 \\
\hline 9 & 23,46 & 1-метилпента-1,3-диеніл бензен & 93 \\
\hline 10 & 24,69 & 2,4-диізопропіл-1-метил-1-вініл циклогексан & 91 \\
\hline 11 & 25,16 & 3,4-диметил циннолін & 90 \\
\hline 12 & 25,37 & 1-етеніл-3-метилен-5-(1-пропеніліден)-циклогексан & 90 \\
\hline 13 & 25,56 & каріоорілен & 99 \\
\hline 14 & 26,36 & 1,1,3-триметил-1Н-інден & 91 \\
\hline 15 & 26,62 & $\alpha$-каріоорілен & 96 \\
\hline 16 & 26,73 & $\beta$-фрарнезен & 93 \\
\hline 17 & 27,48 & гермакрен-D & 98 \\
\hline 18 & 27,92 & 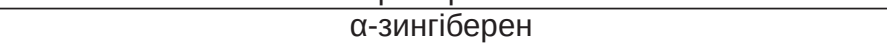 & 94 \\
\hline 19 & 28,33 & $\beta$-бісаболен & 94 \\
\hline 20 & 28,79 & $\beta$-сесквіфеландрен & 93 \\
\hline 21 & 29,53 & 1,3-диметилнасртален & 95 \\
\hline 22 & 30,93 & $\beta$-гур'юнен & 98 \\
\hline 23 & 31,82 & алло-аромадендрен & 89 \\
\hline 24 & 33,11 & 2-(2-піридил) циклогексанол & 92 \\
\hline 25 & 34,33 & 7-метил-4-(1-метилетиліден) біцикло [5.3.1] ундец-1-ен-8-ол & 86 \\
\hline 26 & 40,53 & n-гексадеканова кислота & 99 \\
\hline 27 & 44,39 & 9,12-октадекадієнова кислота & 99 \\
\hline
\end{tabular}

ВИСНОВКИ. У статті наведено результати дослідження компонентного складу летких фрракцій сировини бедринцю ломикаменевого:

1. Методом газової хромато-мас-спектрометрії досліджено якісний склад летких сполук бедринцю ломикаменевого трави та кореневищ і коренів. У траві виявлено 59 компонентів, ідентифріковано 26. У кореневищах і коренях ідентифріковано 27 компонентів із 65 виявлених.

2. Основними компонентами бедринцю ломикаменевого трави є гермакрен-D, $\beta$-бісаболен, гептакозан, нонакозан; кореневищ і коренів каріофілен, n-гексадеканова і 9,12-октадекадієнова кислоти, гермакрен-D та $\beta$-гур'юнен. Спільними компонентами підземних і надземних органів рослини $€ \beta$-срарнезен, гермакрен-D, $\beta$-бісаболен, 1,3-диметилнафтален та $n$-гексадеканова кислота.

3. Встановлено маркерну сполуку леткої фрракції бедринцю ломикаменевого трави -

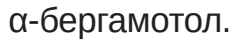

\section{СПИСОК ЛІТЕРАТУРИ}

1. Українська радянська енциклопедія : у 12 т. / гол. ред. М. П. Бажан ; редкол. : О. К. Антонов та ін. 2-ге вид. - К. : Головна редакція УРЕ, 1974-1985.

2. Рослини для нас : довідковий посібник / за ред. Г. П. Яковлєва, К. Ф. Блінова. - СПб. : Навчальна книга, 1996. - 654 с.

3. Трави і здоров'я. Лікарські рослини / авт.-упоряд. : А. М. Задорожний. - М. : Гамма Прес, 2001. $512 \mathrm{c}$.

4. Марчишин С. М. Визначення вмісту гідроксикоричних кислот у траві та підземних органах бедринцю ломикаменевого / С. М. Марчишин, Е. А. Панасюк //
Хімія природних сполук : матеріали IV Всеукр. наук.практ. конфр. $з$ міжнар. участю (Тернопіль, 21-22 квіт. 2016 р.). - Тернопіль : ТДМУ, 2016. - С. 142.

5. Phenolic compounds from Pimpinella saxifraga L. / S. Marchyshyn, E. Parashchuk, I. Dakhym, L. Husak // The Pharma Innovation Journal. - 2018. 7 (6). - P. 600-602.

6. Comparative analysis of essential oil components of two Daucus species from Algeria and their antimicrobial activity [Text] / N. Meliani, A. DibMohammed El, H. Allali, B. Tabti // International Research Journal of Biological Sciences. - 2013. - 2 (1). - P. 22-29. 
7. Direct resistively heated column gas chromatography (Ultrafast module-GC) for highspeed analysis of essential oils of differing complexities / C. Bicchi, C. Brunelli, C. Cordero [et al.] // J. Chromatogr. A. 2004. - 1024, No. 1-2. - P. 195-207.

8. Марчишин С. М. Визначення летких сполук чистецю Зібольда (Stachys sieboldii MIQ.) / C. M. Map- чишин, Л. В. Гусак, О. Л. Демидяк // Фітотерапія. Часопис. - 2017. - № 3. - С. 64-67.

9. Черногород Л. Б. Эфирные масла некоторых видов рода Achillea L., содержащие сррагранол / Л. Б. Черногород, Б. А. Виноградов // Раст. ресурсы. 2006. - 42, вып. 2. - С. 61-68.

\section{REFERENCES}

1. Bazhan, M.P. (Ed.). (1974-1985). Ukrainska radianska entsyklopediia [Ukrainian soviet encyclopedia]. Antonov, O.K. (editorial board). Kyiv: Holovna redaktsiia URE [in Ukrainian].

2. Yakovliev, H.P., Blinov, K.F. (Ed.). (1996). Roslyny dlia nas. Dovidkovyi posibnyk [Plants for us. Help guide]. Publishing house: Navchalna knyha [in Ukrainian].

3. Zadorozhnyi, A.M. (2001). Travy i zdorovia. Likarski roslyny [Herbs and health. Medicinal plants]. Moscow: Hamma Press [in Ukrainian].

4. Marchyshyn, S.M., \& Panasiuk, E.A. (2016). Vyznachennia vmistu hidroksykorychnykh kyslot u travi ta pidzemnykh orhanakh bedryntsiu lomykamenevoho [Determination of the content of hydroxycinnamic acids in the grass and subterranean organs of the burnet saxifrage]. Khimiia pryrodnykh spoluk: Materialy IV Vseukr. nauk.-prakt. konf. z mizhnar. uchastiu-Chemistry of Natural Compounds: Materials IV All Ukrainian Scientific-Practical Conference with International Participation. Ternopil, April 21-22. Ternopil: "Ukrmedknyha" [in Ukrainnian].

5. Marchyshyn, S., Parashchuk, E., Dakhym, I., \& Husak, L. (2018). Phenolic compounds from Pimpinella saxifraga L. The Pharma Innovation Journal, 7 (6), 600602.

6. Meliani, N., DibMohammed, A. El., Allali, H., \& Tabti, B. (2013). Comparative analysis of essential oil components of two Daucus species from Algeria and their antimicrobial activity. International Research Journal of Biological Sciences, 2 (1), 22-29.

7. Bicchi, C., Brunelli, C., \& Cordero, C. (2004). Direct resistively heated column gas chromatography (Ultrafast module-GC) for highspeed analysis of essential oils of differing complexities. J. Chromatogr. A., 1024 (1-2), 195-207.

8. Marchyshyn, S.M., Husak, L.V., \& Demydiak, O.L. (2017). Vyznachennia letkykh spoluk chystetsiu Zibolda Зібольда (Stachys sieboldii MIQ.) [Determination of volatile compounds of stachys (Stachys sieboldii MIQ.)]. Fitoterapiia. Chasopys - Phytotherapy. Journal, 3, 64-67 [in Ukrainian].

9. Chernogorod, L.B., \& Vinogradov, B.A. (2006). Efirnye masla nekotorykh vidov roda Achillea L., soderzhashchie fragranol [Essential oils of some species of the genus Achillea L., containing fragranol]. Rast. Resursy - Plant Resources, 42 (2), 61-68 [in Russian].

Э. А. Паращук, С. М. Марчишин, Л. В. Слободянюк ТЕРНОПОЛЬСКИЙ ГОСУДАРСТВЕННЫЙ МЕДИЦИНСКИЙ УНИВЕРСИТЕТ ИМЕНИ И. Я. ГОРБАЧЕВСКОГО

\section{ИССЛЕДОВАНИЕ ЛЕТУЧИХ КОМПОНЕНТОВ БЕДРИНЦА КАМНЕЛОМКОВОГО (PIMPINELLA SAXIFRAGA L.)}

\section{Резюме}

Вступление. В Украине произрастает 5 видов растений рода Бедринец семейства сельдерейные (Apiaceae). Наиболее распространенным является бедринец камнеломковый (Pimpinella saxifraga L.) многолетнее травянистое растение, типичный представитель рода Pimpinella. На сегодняшний день достаточно информации относительно его применения в народной медицине: отвары подземных органов растения как отхаркивающее средство при длительном кашле, фрарингите, ларингите, mрахеите и хроническом бронхите; при лечении заболеваний желудочно-кишечного тракта (метеоризм, нарушение пищеварения, хронический гастрит, энтероколит). Используют растение также как противовоспалительное и гипотензивное средство. 
В доступных источниках научной литературы недостаточно инфрормации о химическом составе бедринца камнеломкового. Отсутствуют сведения об исследовании его летучих соединений. В связи с этим и тем, что эфирные масла представителей семейства Аріасеае широко применяют в народной и научной медицине как антибактериальные, противогрибковые, противовирусные, противопаразитарные, инсектицидные, спазмолитические, отхаркивающие, противовоспалительные средства, целью исследования было изучить летучие соединения бедринца камнеломкового травы и корневищ и корней, установить их компонентный состав.

Методы исследования. Компонентный состав летучих соединений исследовали хроматографрическим методом на хромато-масс-спектрометрической системе Agilent 6890N/5973 inert (Agilent Technologies, США). Идентификацию компонентов пробы осуществляли с использованием библиотеки масс-спектров NIST 02.

Результаты и обсуждение. В результате проведенных исследований в бедринца камнеломкового траве обнаружено 59 компонентов летучих соединений, из них идентифицировано 26, основными из которых являются гермакрен-D, $\beta$-бисаболен, гептакозан и нонакозан. B траве исследуемого объекта выявлено сесквитерпеновый спирт - $\alpha$-бергамотол, который может быть маркерным соединением летучей фрракции травы растения. B Pimpinella saxifraga L. корнях обнаружено 65 компонентов летучих соединений, из них идентифицировано 27, основными из которых являются кариофилен, n-гексадекановая и 9,12-октадекадиеновая кислоты, гермакрен-D и $\beta$-гурьюнен. Общими компонентами бедринца камнеломкового травы и подземных органов являются $\beta$-фрарнезен, гермакрен- $D$, $\beta$-бисаболен, 1,3-диметилнафртален и n-гексадекановая кислота.

Выводы. Методом газовой хромато-масс-спектрометрии исследован качественный состав летучих соединений бедринца камнеломкового травы и корневищ и корней. В траве выявлено 59 компонентов, идентифрицировано 26. В корневищах и корнях идентифрицировано 27 компонентов из 65 обнаруженных. Основными компонентами бедринца камнеломкового травы являются гермакрен- $D$, $\beta$-бисаболен, гептакозан, нонакозан; корневищ и корней - кариофилен, n-гексадекановая и 9,12-октадекадиеновая кислоты, гермакрен-D и $\beta$-гурьюнен. Общими компонентами подземных и надземных органов растения являются $\beta$-фрарнезен, гермакрен-D, $\beta$-бисаболен, 1,3-диметилнафртален и n-гексадекановая кислота. Установлено маркерное соединение летучей фрракции бедринца камнеломкового травы - $\alpha$-бергамотол.

КЛЮЧЕВЫЕ СЛОВА: бедринец камнеломковый; трава; корневища и корни; газовая хромато-массспектрометрия; летучие соединения.

E. A. Parashchuk, S. M. Marchyshyn, L. V. Slobodianiuk I. HORBACHEVSKY TERNOPIL STATE MEDICAL UNIVERSITY

\section{RESEARCH OF VOLATILE COMPONENTS OF BURNET SAXIFRAGE (PIMPINELLA SAXIFRAGA L.)}

\section{Summary}

Introduction. There are 5 species of plants of the Pimpinella species Celery family (Apiaceae) in Ukraine. The most common is burnet saxifrage (Pimpinella saxifraga L.), a perennial herb, a typical representative of the Pimpinella species. To date, there is ample information about the use of burnet saxifrage in the folk medicine - decoctions of subterranean organs of a plant are used as an expectorant for prolonged cough, pharyngitis, laryngitis, tracheitis and chronic bronchitis; in the treatment of gastric diseases (flatulence, disorders of digestion, chronic gastritis, enterocolitis). It is also used as an anti-inflammatory and anti-hypertensive agent.

In accessible sources of scientific literature there is not enough information on the chemical composition of the burnet saxifrage. There is no information about the study of its volatile compounds. Taking into account that the essential oils of the Apiaceae family are widely used in folk and scientific medicine as antibacterial, antifungal, antiviral, antiparasitic, insecticidal, antispasmodic, expectorant, anti-inflammatory drugs, as well as the fact that in accessible sources of scientific literature there is not enough information on the chemical composition of the burnet saxifrage, there is no information about the study of its volatile compounds the aim of the study was to learn the volatile compounds of the burnet saxifrage of rhizomes and roots, and to establish their component composition.

Research Methods. Component composition of volatile compounds was investigated by chromatographic method on the Agilent 6890N/5973 inert chromatographic mass spectrometric system (Agilent Technologies, USA). Identification of sample components was carried out using the NIST 02 mass spectrometry library. 
Results and Discussion. As a result of studies in the grass of burnet saxifrage, the 59 components of volatile compounds were revealed, of which 26 were identified, the main were germacrene- $D, \beta$-bisabolin, heptacosan and nonacosan. In the grass of the investigated object, sesquiterpene alcohol - $\alpha$-bergamotol, which may be a marker compound of the volatile fraction of the grass of the burnet saxifrage, was detected. 65 components of volatile compounds were revealed in the roots of Pimpinella saxifraga $L$., 27 among them were identified. The main compounds are cariofilin, $n$-hexadecanoic and 9,12-octadecadienoic acids, hermakren- $D$ and $\beta$-guryunene. Common components are herbs and subterranean organs of the burnet saxifrage: $\beta$-farnesene, germacrene- $D, \beta$-bisabolene, 1,3-dimethylnaphthalene and n-hexadecanoic acid.

Conclusions. The method of gas chromatographic mass spectrometry was used to investigate the qualitative composition of volatile compounds of the the burnet saxifrage grass, and roots and rhizomes. In the grass, 59 components were revealed, 26 - identified. In rhizomes and roots, 27 components were identified from 65 revealed. The main components of the burnet saxifrage grass thigh are germakren- $D, \beta$-bisabolin, heptacosan, nonacosan; rhizomes and roots - kariofilen, $n$-hexadecanoic and 9,12-octadecadienoic acids, germakren- $D$ and $\beta$ - guryunene. The common components of the subterranean and aboveground organs of the plant are $\beta$-farnesene, germacrene- $D$, $\beta$-bisabolene, 1,3-dimethylnaphthalene and $n$-hexadecanoic acid. The marker compound of the volatile fraction from the grass of the burnet saxifrage - $\alpha$-bergamotol was established.

\section{KEY WORDS: burnet saxifrage; grass and rhizomes and roots; gas chromatographic mass spectrometry; volatile compounds.}

Адреса для листування: С. М. Марчишин, Тернопільський державний медичний університет імені І. Я. Горбачевського, майдан Волі, 1, Тернопіль, 46001, Україна, e-mail: marchyshyn@tdmu.edu.ua. 